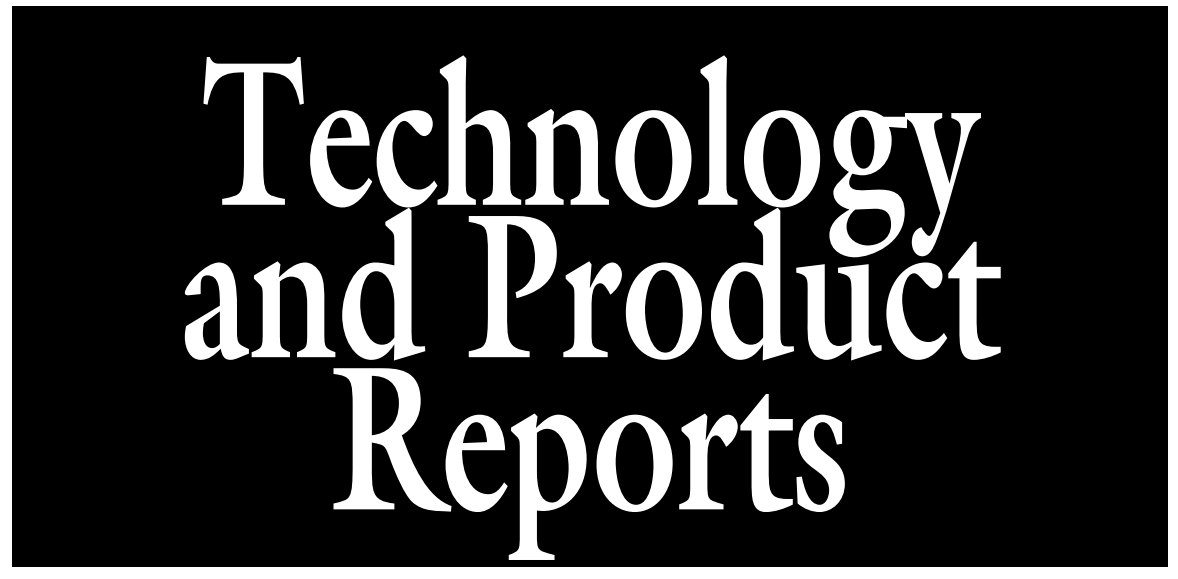

\section{Autonomous Rotary Mower versus Ordinary Reel Mower-Effects of Cutting Height and Nitrogen Rate on Manila Grass Turf Quality}

\author{
Michel Pirchio ${ }^{1}$, Marco Fontanelli, Christian Frasconi, \\ Luisa Martelloni, Michele Raffaelli, Andrea Peruzzi, \\ Lisa Caturegli, Monica Gaetani, Simone Magni, Marco Volterrani, \\ and Nicola Grossi
}

ADDITIONAL INDEX wORDs. mowing, warm season turfgrass, sports surface, custom modified, prototype, Zoysia matrella

\begin{abstract}
SUMMARY. High-quality sports turfs often require low mowing and frequent maintenance. Sports turfs often consist of hard-to-mow warm season turfgrasses, such as zoysiagrass (Zoysia sp.) or bermudagrass (Cynodon sp.). Although autonomous mowers have several advantages over manually operated mowers, they are not designed to mow lower than $2.0 \mathrm{~cm}$ and are consequently not used on high-quality sports turfs. All autonomous mowers are only equipped with rotary mowing devices and do not perform clipping removal. An ordinary autonomous mower was modified to obtain a prototype autonomous mower cutting at a low height. The prototype autonomous mower was tested on a manila grass (Zoysia matrella) turf and compared its performance in terms of turf quality and energy consumption with an ordinary autonomous mower and with a gasoline reel mower. A three-way factor experimental design with three replications was adopted. Factor A consisted of four nitrogen rates $\left(0,50,100\right.$, and $\left.150 \mathrm{~kg} \cdot \mathrm{ha}^{-1}\right)$, factor $B$ consisted of two mowing systems (autonomous mower vs. walk-behind gasoline reel mower with no clipping removal), and factor $\mathrm{C}$ consisted of two mowing heights $(1.2$ and $3.6 \mathrm{~cm})$. Prototype autonomous mower performed mowing at $1.2-\mathrm{cm}$ mowing height whereas ordinary autonomous mower mowed at $3.6-\mathrm{cm}$ mowing height. The interaction between the mowing system and mowing height showed that the turf quality was higher when the turf was mowed by the autonomous mower and at $1.2 \mathrm{~cm}$ than at $3.6 \mathrm{~cm}$. Autonomous mowing not only reduced the mowing quality, but also reduced the leaf width. Lower mowing height induced thinner leaves. Nitrogen fertilization not only increased the overall turf quality, reduced weed cover percentage, but also reduced mowing quality. Autonomous mowers also had a lower energy consumption if compared with the reel mower ( $1.86 \mathrm{vs.} 5.37 \mathrm{kWh} /$ week at $1.2-\mathrm{cm}$ mowing height and $1.79 \mathrm{vs} .2 .32 \mathrm{kWh} /$ week at $3.6-\mathrm{cm}$ mowing height, respectively). These results show that autonomous mowers can perform low mowing even on tough-to-mow turfgrass species. They could also be used on highquality sports turfs, thus saving time as well as reducing noise and pollution.
\end{abstract}

$\mathrm{T}$ he most common warm-season turfgrasses for golf course fairways and tees in the United States are bermudagrass and secondly zoysiagrass (Trappe et al., 2011). The increasing popularity and availability of zoysiagrass cultivars have enabled zoysiagrass to be considered as a suitable turfgrass for sports turfs and golf courses (Patton et al., 2017; Pompeiano et al., 2012, 2014). Zoysiagrass has the most rigid leaves of all turfgrass species, followed by bermudagrass and by the other warm season turf species (Turgeon, 2012). Because of their very high plant fiber hemicellulose content, zoysiagrass leaves have an improved wear tolerance (Lulli et al., 2012; Shearman and Beard, 1975; Turgeon, 2012). However, the high neutral detergent fiber content makes zoysiagrass more difficult to mow. Thus, to have a high mowing quality, mowers working constantly on zoysiagrass require more sharpening than mowers working on other grasses (Bevard et al., 2005). Being so hard to mow, manila grass cultivars tend to have a lower quality of cut than japanese lawngrass (Zoysia japonica) cultivars (Patton et al., 2010). The optimal mowing height for zoysiagrasses ranges from 0.25 to $6.4 \mathrm{~cm}$ (Patton et al., 2017). Mowing heights ranging from 1.5 to $2 \mathrm{~cm}$ tend to stimulate a faster greening of zoysiagrass in early spring (Lee and Kim, 2005). Historically, zoysiagrass cultivars were developed for lawn use; however, they have a high genetic variability, which results in several morphological differences (Anderson, 2000; Magni et al., 2017). Although the use of zoysiagrass on putting greens in the United States is very recent (Morris, 2016), the use of zoysiagrass for golf greens, tees, and fairways has been encouraging (Engelke et al., 2002a, 2002b; Whereley et al., 2011). Typically, turfgrass mowers are divided into three main groups: rotary mowers, reel mowers, and flail mowers. Rotary mowers cut the grass by hitting it with a revolving single blade and are most effective at mowing tall grass and mulching clippings. However, rotary mowers are not suitable for mowing at low heights and often result in scalping (Munshaw, 2013). Reel mowers instead cut the grass with a scissor-like action using a reel cylinder and a bed knife. Reel mowers perform optimal mowing at a short height (below $2.5 \mathrm{~cm}$ ) and are suitable for tough-to-mow grasses such as zoysiagrass and bermudagrass (Munshaw, 2013). Reel mowers are, thus, usually chosen for golf courses and sports turfs. Because of their 
scissor-like cutting action, reel mowers have a higher quality of cut compared with rotary mowers and cause less damage to the leaf blades, producing a better looking turf and up to $65 \%$ fewer diseases (Beard and Eaton, 1973). However, there is a kind of rotary mower that has proven to produce a superior turf quality compared with traditional walk-behind rotary mowers: autonomous mowers (Grossi et al., 2016; Pirchio et al., 2018). Time savings, no polluting gasses, preventing contact with allergens, energy saving, and very low noise are just some of the advantages of using autonomous mowers (Hicks and Hall, 2000; Ragonese and Marx, 2015). Modern autonomous mowers are battery powered and perform lawn mowing without the need for an operator. Unlike walk-behind rotary mowers, autonomous mowers are not designed to collect clippings. Autonomous mowers are, thus, usually programmed to operate every day to produce just very small clippings. Through a process called "grasscycling," the small clippings can easily be integrated into the turfgrass without forming thatch (Brede, 2000). The cutting system of autonomous mowers usually consists either of a cutting disc with small pivoting blades mounted on it (Honda, 2018; Husqvarna, 2018), or solid blades with three or four cutting edges (Robomow, 2018; Zucchetti, 2018). However, whether an autonomous mower can equal the quality of cut of a reel mower is not yet clear. A previous trial has been carried out to compare the differences in terms of turf quality and mowing quality between an autonomous mower and a reel mower (Ferguson and Newell, 2010). In terms of overall turf quality, the autonomous mower and the reel mower produced similar results. Labor was significantly reduced by the autonomous mower, with respect to the cylinder mower. The authors suggest that the autonomous mower

We sincerely thank FERCAD S.p.a. Company (Altavilla Vicentina, Vicenza, Italy) for providing technical support and Rossi Macchine Agricole Company (Ponte a Egola, San Miniato, Pisa, Italy) for providing technical assistance.

Department of Agriculture, Food and Environment, University of Pisa, Pisa 56124, Italy

${ }^{1}$ Corresponding author. E-mail: michel.pirchio@for. unipi.it.

https://doi.org/10.21273/HORTTECH04064-18 tested in the trial may be a valid alternative to reel mowers at mowing heights greater than $2.5 \mathrm{~cm}$. In the scientific literature, no autonomous mower has ever been tested at a very low mowing height. Theoretically, autonomous mowers may reach a minimum of $2.0 \mathrm{~cm}$ mowing height. It is still not clear if an autonomous mower can perform mowing on a sports turf, which requires very low mowing heights, or on a hard-tomow turfgrass species such as zoysiagrass. The aim of this trial was to develop and test a prototype-autonomous mower cutting at a low height on a manila grass turf, and to compare its performance in terms of turf quality and energetic aspects with an ordinary autonomous mower and with a gasoline reel mower. The trial was carried out to simulate a golf tee and a golf rough, with different mowing heights, different fertilization rates and with one of the most difficult turf species to mow; i.e., manila grass.

\section{Materials and methods \\ The experimental trial}

The experimental trial was carried out at the Center for Research on Turfgrass for Environment and Sports (CeRTES) of the Department of Agriculture, Food, and Environment of Pisa University, Pisa, Italy (lat. $43^{\circ} 40^{\prime} \mathrm{N}$, long. $10^{\circ} 19^{\prime} \mathrm{E}$, elevation $6 \mathrm{~m}$ ) from Apr. to Oct. 2016 on a mature stand of 'Zeon' manila grass. The stand was established on a soil characterized by the following physicochemical properties: silt loam (Calcaric Fluvisol, 30\% sand, 51\% silt and $19 \%$ clay) with a $\mathrm{pH}$ of 7.7 and $22 \mathrm{~g} \cdot \mathrm{kg}^{-1}$ organic matter. From 18 Apr. 2016, manual mowing was carried out once per week at $2.0 \mathrm{~cm}$ to help the turf adapt to the future mowing heights. Irrigation was applied as necessary to avoid wilt turf. On 27 June 2016, a three-way factor experimental design $(\mathrm{A} \times \mathrm{B} \times \mathrm{C})$ with three replications was adopted.

Factor A consisted of four levels of nitrogen $(\mathrm{N})$ fertilization applied: $0,50,100$, and $150 \mathrm{~kg} \cdot \mathrm{ha}^{-1} \mathrm{~N}(\mathrm{am}-$ monium sulfate $21 \mathrm{~N}-0 \mathrm{P}-0 \mathrm{~K})$. Factor $\mathrm{B}$ consisted of two mowing systems: 1) autonomous mowing with an ordinary autonomous mower and with a prototype autonomous mower and 2) manual mowing with a walkbehind gasoline reel mower with no clipping removal. Factor $\mathrm{C}$ consisted in two mowing heights: 1.2 or $3.6 \mathrm{~cm}$.

In particular, the prototype autonomous mower was set at $1.2-\mathrm{cm}$ mowing height and the ordinary autonomous mower was set at $3.6-\mathrm{cm}$ mowing height. The reel mower was set at $1.2-$ or $3.6-\mathrm{cm}$ mowing height depending on which plot needed to be mown. The cutting frequency of the reel mower was once per week at $3.6-\mathrm{cm}$ mowing height and twice per week at $1.2-\mathrm{cm}$ mowing height. Both the ordinary autonomous mower and the prototype autonomous mower operated every day and were set at $7.2 \mathrm{~h} \cdot \mathrm{d}^{-1}$ working time. Both autonomous mowers used the same cutting blades. All autonomous mowers in this trial were set in energy saving (ECO) mode. This means that the boundary wires consumed energy only when the autonomous mowers were out of the charging stations. The blades of the reel mower were lapped weekly before each mowing and the blades of both autonomous mowers were replaced every 2 weeks.

\section{Description of the machines}

REEL MOWER. A self-propelled reel mower (20-3.5 RP-7; McLane, Paramount, CA) was used in this trial. The working width is $50 \mathrm{~cm}$. It is

\begin{tabular}{llll}
\hline $\begin{array}{l}\text { Units } \\
\text { To convert U.S. to SI, } \\
\text { multiply by }\end{array}$ & U.S. unit & SI unit & $\begin{array}{l}\text { To convert SI to U.S., } \\
\text { multiply by }\end{array}$ \\
\hline 10 & $\%$ & $\mathrm{~g} \cdot \mathrm{kg}^{-1}$ & 0.1 \\
0.3048 & $\mathrm{ft}$ & $\mathrm{m}$ & 3.2808 \\
0.0929 & $\mathrm{ft}^{2}$ & $\mathrm{~m}^{2}$ & 10.7639 \\
3.7854 & gal & $\mathrm{L}$ & 0.2642 \\
0.7457 & horsepower & $\mathrm{kW}$ & 1.3410 \\
2.54 & inch(es) & $\mathrm{cm}$ & 0.3937 \\
25.4 & inch(es) & $\mathrm{mm}$ & 0.0394 \\
6.4516 & inch & $\mathrm{cm}$ & 0.1550 \\
16.3871 & inch & $\mathrm{cm}^{2}$ & 0.0610 \\
3.6000 & $\mathrm{kWh}$ & $\mathrm{MJ}$ & 0.2778 \\
1.1209 & lb/acre & $\mathrm{kg} \cdot \mathrm{ha}^{-1}$ & 0.8922 \\
1.6093 & $\mathrm{mph}$ & $\mathrm{km} \cdot \mathrm{h}^{-1}$ & 0.6214 \\
& & &
\end{tabular}


equipped with a seven-blade reel and with a single-cylinder gasoline engine (Briggs \& Stratton, Wauwatosa, WI), with an output of $2.6 \mathrm{~kW}$. It has a belt drive with no speed variation. Engine displacement is $148 \mathrm{~cm}^{3}$. Mowing height can be adjusted from 0.6 to $3.8 \mathrm{~cm}$.

ORDINARY AUTONOMOUS MOWER. An autonomous mower (Automower 310; Husqvarna, Stockholm, Sweden) was used in this trial. It is a small autonomous mower equipped with two front pivoting wheels and two rear course-treaded driving wheels. It has three small pivoting blades mounted on a 22 -cm-wide cutting disc. Mowing height is adjusted manually and ranges from 2.0 to $6.0 \mathrm{~cm}$. The cutting disc and the driving wheels are powered by brushless electric motors. Maximum working capacity is $1000 \mathrm{~m}^{2}$ for a $24 \mathrm{~h} \cdot \mathrm{d}^{-1}$ working time.

PROTOTYPE AUTONOMOUS MOWER. The prototype autonomous mower was obtained by modifying a second autonomous mower (Automower 310) to achieve lower mowing heights, ranging from 0.3 to $4.0 \mathrm{~cm}$ (Figs. 1 and 2). Because of its manual mowing height adjustment, this autonomous mower was the most appropriate machine to start with to obtain the lowmowing prototype. In fact, manual adjustment enables the mowing height to be changed with a continuous variation, allowing even for the slightest adjustment. The first modification was to build a $2-\mathrm{cm}$ spacer to lower the cutting disc. The spacer was placed between the shaft coming from the cutting disc engine and the cutting disc itself. The spacer was built from a piece of alloy and lathed to obtain a lightweight and reliable component. The second modification was to remove the loose stainless steel disc placed under the cutting disc. The purpose of the loose disc was to save energy by preventing the grass from coming into contact with the revolving cutting disc. After the spacer was mounted, the loose disc became an obstacle to low mowing as it touched the ground before the cutting disc, thus, the cutting disc could not get lower than $1.1 \mathrm{~cm}$. Removing the loose disc allowed the cutting disc to almost reach ground level, and thus to cut at (theoretically) $0.3 \mathrm{~cm}$. The third modification was to stop the three small blades from pivoting by changing the type of screws used to

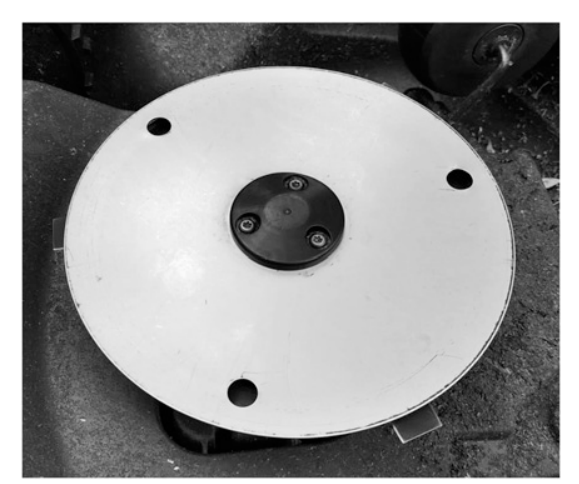

Fig. 1. Cutting disc of the ordinary autonomous mower. Note the stainless loose disc and the pivoting cutting blades underneath.

mount them on the cutting disc. The need to stop the blades from pivoting was because very low turfgrass offered more resistance to mowing, thus, the pivoting blades ended up being constantly retracted and did not perform a proper cutting.

\section{Experimental field and data collection}

The entire area was $1200 \mathrm{~m}^{2}$ $(60 \times 20 \mathrm{~m})$, with 48 experimental plots, each of $25 \mathrm{~m}^{2}(5 \times 5 \mathrm{~m})$. At 4,8 , 12 , and 16 weeks after treatment (WAT), the following parameters were assessed on the turf: turf quality: ( 1 = poor, 9 = excellent $), 6$ is considered an acceptable score (Morris and Shearman, 2018); mowing quality: ( 1 = unevenly cut edge of leaf blade with visible veins some millimeters long; 9 = perfectly cut edge of leaf blade) 6 is considered an acceptable score; weed cover (\%): expressed as weed percentage of total groundcover; and disease: $(1=100 \%$ injury, $9=0 \%$ injury) (Morris and Shearman, 2018). At 16 WAT, a $50-\mathrm{cm}^{2}$ core sample per plot was collected, and the following parameters were determined: Leaf width: 20 fully expanded leaves per plot were collected and attached on a sheet of paper. Digital imagery was acquired using a scanner. Enlarged pictures of the leaves were printed and measured. Data were reported in millimeters. Shoot density was determined by direct counting, with data reported in shoot per square centimeter. From 27 June to 17 Oct., working speed, working time, turning time, working capacity, power requirement, electrical energy requirement, and gasoline consumption were assessed. A power consumption meter

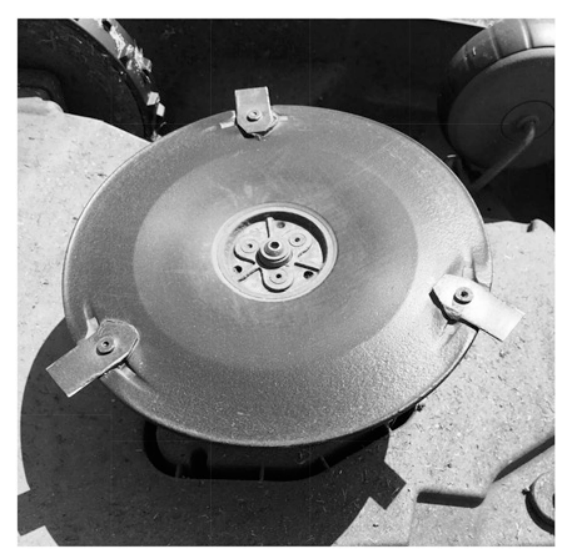

Fig. 2. Cutting disc of the prototype autonomous mower. The cutting disc has been custom modified by removing the loose disc and securing the three cutting blades to stop them from pivoting.

(EL-EPM02HQ; Nedis,'s-Hertogenbosch, the Netherlands) was used to assess the electrical energy requirement. The gasoline tank was filled just before mowing. Gasoline consumption was measured by refueling the tank after mowing.

\section{Statistical analysis}

Statistical analyses were carried out with COSTAT software (version 6.400; CoHort Software, Monterey, CA). All data were analyzed by a three-way analysis of variance and an all-pairwise Fisher's least significant difference test at the probability level of 0.05 .

\section{Results}

There was no significant threeway interaction between factors. However, there was a significant interaction between the mowing system (factor B) and mowing height (factor C). $\mathrm{N}$ fertilization rate had a significant effect on turf quality, mowing quality, weed cover percentage, leaf width, and shoot density. Mowing system had a significant effect on mowing quality and on leaf width but did not affect the weed cover percentage. Mowing height had a significant effect on leaf width. Turf disease was not significantly affected by any of the treatments performed.

The interaction between the mowing system and mowing height at 4,8 , and 12 WAT showed that turf quality was higher when the turf was mowed by the autonomous mower and also when the turf was mowed at $1.2 \mathrm{~cm}$ than at $3.6 \mathrm{~cm}$ (Table 1 ). The 
interaction between the mowing system and mowing height also showed that the increase in turf quality due to the use of the autonomous mower was higher at $1.2 \mathrm{~cm}$ than at $3.6 \mathrm{~cm}$ (Table 1). At 16 WAT, the reel mower has the opposite effect on turf quality than at 4,8 , and 12 WAT. In fact, turf quality was higher at a 3.6$\mathrm{cm}$ than at a $1.2-\mathrm{cm}$ mowing height (6.6 vs. 6.3, respectively) (Table 1 ). At 16 WAT, the autonomous mower produced higher turf quality values compared with the reel mower. The autonomous mower also produced superior turf quality at the $1.2-\mathrm{cm}$ mowing height (6.9 vs. 6.7 , respectively), in line with the results obtained at 4,8 , and 12 WAT (Table 1). Shoot density (Table 2) was

Table 1. Mowing system and mowing height interaction effect on manila grass turf quality $(1=$ poor, $9=$ excellent $)$ after $4,8,12$, and 16 weeks of treatment.

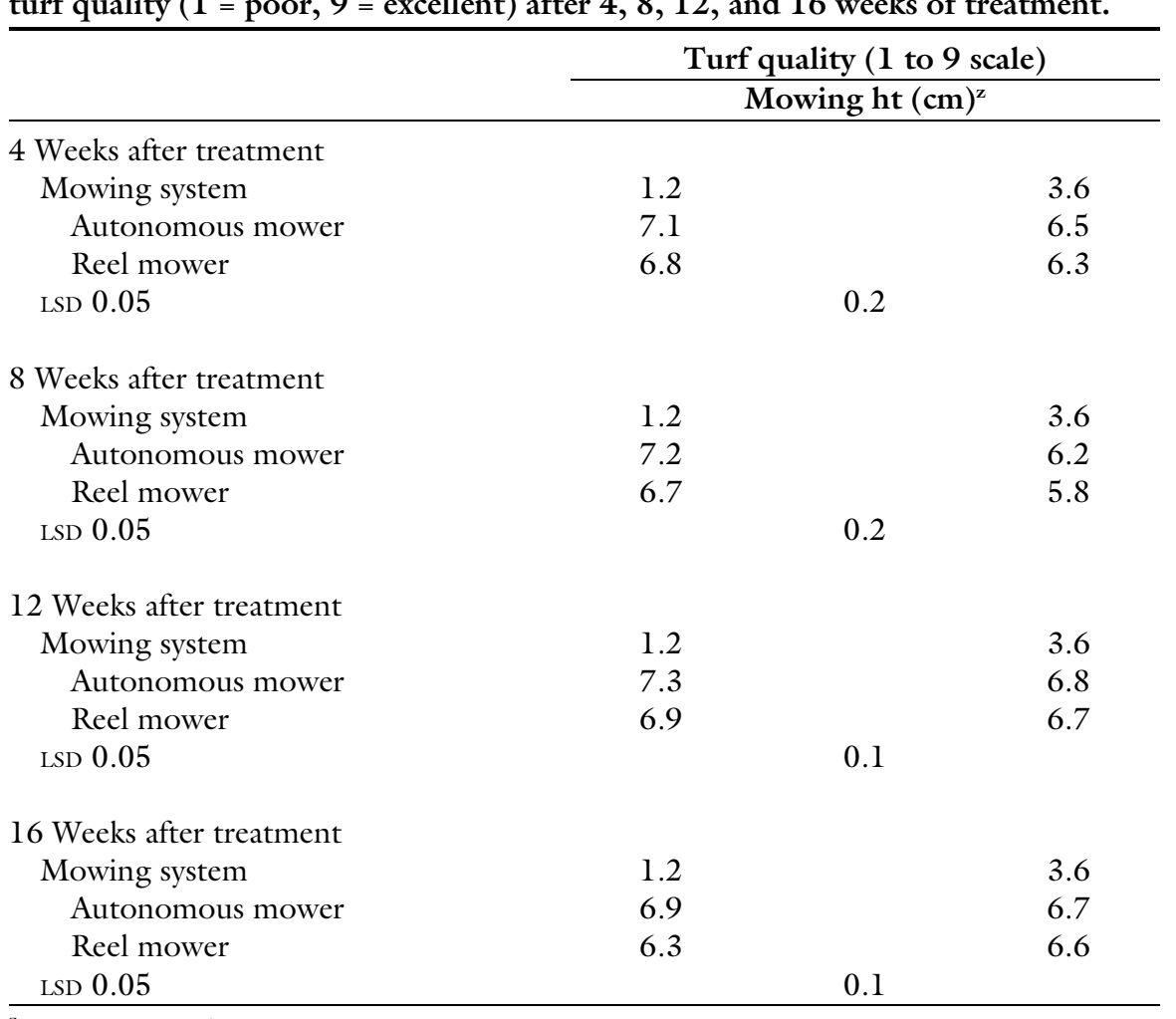

${ }^{\mathrm{z}} 1 \mathrm{~cm}=0.3937$ inch.

Table 2. Mowing system and mowing height interaction effect on manila grass shoot density after 16 weeks of treatment.

\begin{tabular}{lcc}
\hline & \multicolumn{3}{c}{ Mowing ht $(\mathrm{cm})^{\mathrm{z}}$} \\
\cline { 2 - 4 } Mowing system & \multicolumn{1}{c}{$\mathbf{l . 2}$} & $\mathbf{3 . 6}$ \\
\cline { 2 - 3 } Autonomous mower & \multicolumn{2}{c}{ Shoot density $\left(\mathrm{shoots} / \mathrm{cm}^{\mathbf{2}}\right)^{\mathrm{z}}$} \\
Reel mower & 9.9 & 6.4 \\
LSD 0.05 & 9.6 & 5.8 \\
\hline
\end{tabular}

${ }^{\mathrm{z}} 1 \mathrm{~cm}=0.3937$ inch, 1 shoot $/ \mathrm{cm}^{2}=6.4516$ shoots $/$ inch $^{2}$. higher when the turf was mowed at $1.2 \mathrm{~cm}$ with both the reel mower and the autonomous mower. In addition, the autonomous mower produced a higher shoot density compared with the reel mower, when the turf was mowed at $1.2 \mathrm{~cm}$. Moreover, the increase in shoot density due to the use of the autonomous mower vs. the reel mower was higher and significant only at a $1.2-\mathrm{cm}$ mowing height (Table 2). All rates of $\mathrm{N}$ fertilization improved turf quality at $4,8,12$, and 16 WAT compared with the control (Table 3 ). The mowing quality behaved inversely in response to $\mathrm{N}$ fertilization compared with turf quality at $4,8,12$, and 16 WAT (Table 3 ). In fact, higher rates of $\mathrm{N}$ fertilization decreased mowing quality (Table 3 ). 
Table 3. Nitrogen fertilization mean effect on manila grass turf quality ( $1=$ poor, $9=$ excellent $)$, mowing quality $(1=$ poor, $9=$ excellent $)$, and weed cover after 4,8 , 12 , and 16 weeks of treatment.

\begin{tabular}{|c|c|c|c|}
\hline $\begin{array}{l}\text { Nitrogen } \\
\text { fertilization }\left(\mathrm{kg} \cdot \mathrm{ha} \mathrm{a}^{-1}\right)^{\mathrm{z}}\end{array}$ & $\begin{array}{l}\text { Turf quality } \\
\text { (1 to } 9 \text { scale) }\end{array}$ & $\begin{array}{l}\text { Mowing quality } \\
\text { ( } 1 \text { to } 9 \text { scale) }\end{array}$ & Weed cover $(\%)$ \\
\hline \multicolumn{4}{|l|}{4 Weeks after treatment } \\
\hline 0 & 5.8 & 7.4 & 3.3 \\
\hline 50 & 6.6 & 7.2 & 0.7 \\
\hline 100 & 7.1 & 6.9 & 0.3 \\
\hline 150 & 7.4 & 6.7 & 0.0 \\
\hline LSD 0.05 & 0.3 & 0.2 & 0.7 \\
\hline \multicolumn{4}{|l|}{8 Weeks after treatment } \\
\hline 0 & 5.6 & 7.3 & 3.7 \\
\hline 50 & 6.3 & 7.2 & 1.0 \\
\hline 100 & 6.8 & 7.2 & 0.3 \\
\hline 150 & 7.3 & 6.9 & 0.0 \\
\hline LSD 0.05 & 0.2 & 0.1 & 0.4 \\
\hline \multicolumn{4}{|l|}{12 Weeks after treatment } \\
\hline 0 & 6.2 & 7.3 & 4.0 \\
\hline 50 & 6.8 & 7.3 & 1.3 \\
\hline 100 & 7.2 & 7.3 & 0.7 \\
\hline 150 & 7.7 & 7.1 & 0.0 \\
\hline LSD 0.05 & 0.2 & 0.1 & 0.8 \\
\hline \multicolumn{4}{|l|}{16 Weeks after treatment } \\
\hline 0 & 5.9 & 7.3 & 6.3 \\
\hline 50 & 6.5 & 7.3 & 1.7 \\
\hline 100 & 7.0 & 7.1 & 1.0 \\
\hline 150 & 7.3 & 6.9 & 0.3 \\
\hline LSD 0.05 & 0.3 & 0.2 & 1.2 \\
\hline
\end{tabular}

${ }^{\mathrm{z}} 1 \mathrm{~kg} \cdot \mathrm{ha}^{-1}=0.8922 \mathrm{lb} / \mathrm{acre}$.

Table 4. Mowing system mean effect on manila grass mowing quality ( $1=$ poor, 9 = excellent) after $4,8,12$, and 16 weeks of treatment.

\begin{tabular}{lcccc}
\hline & \multicolumn{4}{c}{ Mowing quality (1 to 9 scale) } \\
\cline { 2 - 5 } Mowing system & $\begin{array}{c}\text { 4 wk after } \\
\text { treatment }\end{array}$ & $\begin{array}{c}\text { 8 wk after } \\
\text { treatment }\end{array}$ & $\begin{array}{c}\text { 12 wk after } \\
\text { treatment }\end{array}$ & $\begin{array}{c}\text { 16 wk after } \\
\text { treatment }\end{array}$ \\
\hline Autonomous mower & 6.8 & 6.8 & 6.8 & 6.6 \\
Reel mower & 7.3 & 7.5 & 7.6 & 7.6 \\
LSD 0.05 & 0.1 & 0.2 & 0.2 & 0.2 \\
\hline
\end{tabular}

Table 5. Nitrogen fertilization mean effect on manila grass leaf width and shoot density after 16 weeks of treatment.

\begin{tabular}{lcc}
\hline $\begin{array}{l}\text { Nitrogen fertilization } \\
\left(\mathbf{k g} \cdot \mathbf{h a}^{-\mathbf{1}}\right)^{\mathrm{z}}\end{array}$ & Leaf width $(\mathbf{m m})^{\mathrm{z}}$ & $\begin{array}{c}\text { Shoot density } \\
\left(\text { shoots } / \mathrm{cm}^{2}\right)^{\mathbf{z}}\end{array}$ \\
\hline 0 & 0.7 & 7.7 \\
50 & 0.9 & 8.3 \\
100 & 0.9 & 9.3 \\
150 & 1.0 & 9.6 \\
LSD 0.05 & 0.1 & 1.0 \\
\hline
\end{tabular}

${ }^{\mathrm{z}} 1 \mathrm{~kg} \cdot \mathrm{ha}^{-1}=0.8922 \mathrm{lb} /$ acre, $1 \mathrm{~mm}=0.0394$ inch, $1 \mathrm{shoot} / \mathrm{cm}^{2}=6.4516$ shoots $/$ inch $^{2}$.

prototype autonomous mower operational time was set at $7.2 \mathrm{~h} \cdot \mathrm{d}^{-1}(50.4 \mathrm{~h} /$ week) for a $300-\mathrm{m}^{2}$ working area, considering both charging time and mowing time (Table 8 ). Total charging time was $3.6 \mathrm{~h} \cdot \mathrm{d}^{-1}(25.2 \mathrm{~h} /$ week) and total mowing time was $3.6 \mathrm{~h} \cdot \mathrm{d}^{-1}(25.2 \mathrm{~h} /$ week $)$. The total energy consumption (boundary wire and battery charging) of the prototype autonomous mower was 0.86 $\mathrm{kWh} /$ week, which corresponds to $1.86 \mathrm{kWh}$ of primary energy (energy from primary sources transformed into electric energy). The power requirement of the boundary wire (which was in ECO mode) was 0.10 $\mathrm{kWh} /$ week because the boundary wire was operative only during mowing and had an average consumption of $4 \mathrm{~W}$. The electric energy consumption required for the battery charging was $0.76 \mathrm{kWh} /$ week. The prototype autonomous mower had an average power consumption of $30 \mathrm{~W}$ during mowing. The walk-behind reel mower set at a $1.2-\mathrm{cm}$ mowing height, was manually operated twice per week, and covered the working area of $300 \mathrm{~m}^{2}$ in $0.4 \mathrm{~h}$. The average working speed was $1.5 \mathrm{~km} \cdot \mathrm{h}^{-1}$. The walk-behind reel mower was equipped with a gasoline engine, which had a fuel consumption of $0.58 \mathrm{~L} /$ week. Primary energy consumption was $2.73 \mathrm{kWh}$ (Table 8). Comparing the weekly management of the two mowing systems (autonomous mowing and manual reel mowing) at both heights, it appears that both autonomous mowers required a much longer mowing time than the reel mower. Both autonomous mowers had a lower energy consumption than the reel mower set at the two mowing heights. Looking at the estimated costs, both autonomous mowers were slightly cheaper than the reel mower (Table 8).

\section{Discussion}

For the entire duration of the trial, autonomous mowing produced a superior turf quality compared with the reel mower at both 1.2 and $3.6-\mathrm{cm}$ mowing heights. Conversely, Ferguson and Newell (2010) observed a higher turf quality produced by an autonomous (model Bigmow; Belrobotics, Wavre, Belgium) vs. a reel mower only 6 months after their trial had started. Ferguson and Newell (2010) also found that the autonomous mower produced a lower weed encroachment compared with the reel mower throughout the trial. Conversely, Pirchio et al. (2018) found that the autonomous mower produced a slightly higher weed encroachment for creeping types of weeds, which may adapt to a constant 
mowing height and grow sideways. Typically, $\mathrm{N}$ fertilization tends to help improve mowing quality because leaf blades are more turgid and become less difficult to cut (Gibeault and Hanson, 1977). However, in this trial mowing quality was reduced by higher rates of $\mathrm{N}$ fertilization. Because manila grass leaves are so rigid (Patton et al., 2017) and more difficult to cut than all other turfgrass species (Turgeon, 2012), the increase in turf biomass produced by higher $\mathrm{N}$ fertilization rates required a higher power to perform high-quality mowing. For this reason, mowing quality

Table 6. Mowing system mean effect on manila grass leaf width after 16 weeks of treatment.

\begin{tabular}{lc}
\hline Mowing system & Leaf width $(\mathbf{m m})^{\mathbf{z}}$ \\
\hline Autonomous & 0.8 \\
$\quad$ mower & \\
Reel mower & 1.0 \\
LSD 0.05 & 0.1 \\
\hline
\end{tabular}

${ }^{\mathrm{z}} 1 \mathrm{~mm}=0.0394$ inch.

Table 7. Mowing height mean effect on manila grass leaf width after 16 weeks of treatment.

\begin{tabular}{lc}
\hline Mowing ht $(\mathrm{cm})^{\mathrm{z}}$ & Leaf width $(\mathrm{mm})^{\mathrm{z}}$ \\
\hline 1.2 & 0.7 \\
3.6 & 1.0 \\
LSD 0.05 & 0.1 \\
\hline
\end{tabular}

${ }^{\mathrm{z}} 1 \mathrm{~cm}=0.3937$ inch, $1 \mathrm{~mm}=0.0394$ inch. was higher when the manila grass turf was mowed with the reel mower because both autonomous mowers had a less powerful mowing system. At a $3.6-\mathrm{cm}$ mowing height, operating the reel mower once per week was enough to respect the one-third rule (meaning that no more than onethird of the grass height should be removed in a single mowing) (Turgeon, 2012), but the average turf height throughout the whole week was obviously higher with respect to the turf mower by the ordinary autonomous mower. Grossi et al. (2016) and Pirchio et al. (2018) also observed that the daily mowing carried out by the autonomous mowers on tall fescue (Festuca arundinacea) kept the average turf height lower if compared with the turf mowed with the rotary mower. However, at the $3.6-\mathrm{cm}$ mowing height, manila grass showed to be less sensitive to mowing frequency because there was a smaller difference in turf quality between the reel and autonomous mowers compared with the $1.2-\mathrm{cm}$ mowing height. Moreover, $1.2 \mathrm{-cm}$ mowing height resulted in a higher turf quality compared with $3.6 \mathrm{~cm}$. This may encourage the use of selected cultivars of manila grass, such as 'Zeon', for sports turf applications and even golf tees, in line with other authors (Engelke et al., 2002a, 2002b).

Regarding energy consumption, Pirchio et al. (2018) found a much lower primary energy requirement for the autonomous mower compared with a walk-behind gasoline rotary mower (2.98 vs. $4.64 \mathrm{kWh} /$ week). In our trial, the autonomous mowers still required less primary energy compared with the reel mower, but the difference in energy requirement was much smaller when mowing was performed at $3.6 \mathrm{~cm}$ (1.79 vs. 2.32 $\mathrm{kWh} /$ week). Comparing the economic costs of the machines, the prototype autonomous mower was considerably cheaper than the reel mower cutting at $1.2 \mathrm{~cm}$ but the ordinary autonomous mower was just slightly cheaper than the reel mower cutting at $3.6 \mathrm{~cm}$ (Table 8 ). The small difference between the cost of the ordinary autonomous mower and the cost of the reel mower is due to the low mowing frequency of the reel mower (once per week). With a higher mowing frequency (as performed for a $1.2-\mathrm{cm}$ mowing height and as performed by our prototype), the ordinary autonomous mower would be considerably cheaper than the reel mower.

\section{Conclusions}

Autonomous mowing improved overall turf quality and shoot density but did not equal the mowing quality of the reel mowers. This is expected because on a hard-to-mow turfgrass species, the scissor-like action of the reel mower is more effective than the

Table 8. Operational characteristics, energy consumption, and estimated costs of ordinary autonomous mower, prototype

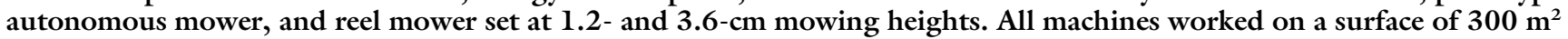
$\left(3229.2 \mathrm{ft}^{2}\right) .^{\mathrm{z}}$

\begin{tabular}{|c|c|c|c|}
\hline \multirow[b]{3}{*}{ Parameter } & \multirow[b]{3}{*}{ Unit $^{\mathrm{z}}$} & \multicolumn{2}{|c|}{ Autonomous mower } \\
\hline & & Prototype & Ordinary \\
\hline & & $1.2 \mathrm{~cm}$ & $3.6 \mathrm{~cm}$ \\
\hline Set daily working time (mowing and recharging) & $h \cdot d^{-1}$ & 7.20 & 7.20 \\
\hline Daily mowing time (no recharging) & $h \cdot d^{-1}$ & 3.60 & 3.80 \\
\hline Electric energy consumption per week & $\mathrm{kWh} /$ week & 0.86 & 0.82 \\
\hline Cost per week & & \multicolumn{2}{|c|}{ Reel mower } \\
\hline Engine power & $\mathrm{kW}$ & 2.60 & 2.60 \\
\hline Working speed & $\mathrm{km} \cdot \mathrm{h}^{-1}$ & 1.50 & 2.00 \\
\hline Working width & $\mathrm{cm}$ & 50.00 & 50.00 \\
\hline
\end{tabular}

${ }^{\mathrm{z}} \mathrm{l} \mathrm{cm}=0.3937 \mathrm{inch}, 1 \mathrm{kWh}=3.6000 \mathrm{MJ}, 1 \mathrm{~kW}=1.3410$ horsepower, $1 \mathrm{~km} \cdot \mathrm{h}^{-1}=0.6214 \mathrm{mph}, 1 \mathrm{~L}=0.2642 \mathrm{gal}$.

${ }^{\mathrm{y}} \mathrm{Without}$ considering the custom modification cost (only purchase cost). 
revolving blades of a rotary mower. Our prototype autonomous mower working at a $1.2-\mathrm{cm}$ mowing height produced a higher quality turf and increased shoot density compared both with the reel mower and to the machines working at a $3.6-\mathrm{cm}$ mowing height. The energy saving was also optimized by both autonomous mowers.

These encouraging results show that autonomous mowers have the potential to perform optimal turf maintenance not only of home lawns and large ornamental areas, but also of quality sports turfs, such as golf tees and golf roughs, even on toughto-mow turfgrass species. Autonomous mowers are not intended to replace human labor, instead they could help to obtain the highest turf quality, thus, saving time and allowing greenkeepers to care for other specialized maintenance operations (i.e., seeding, fertilization, and weeding).

Further research is needed to determine whether autonomous mowers can perform mowing at an even lower mowing height such as on golf greens, where daily mowing is mandatory.

\section{Literature cited}

Anderson, S.J. 2000. Taxonomy of Zoysia (Poaceae): Morphological and molecular variation. Texas A\&M Univ., College Station, TX, PhD Diss.

Beard, J.B. and J. Eaton. 1973. Reel versus rotary mower comparisons. Michigan State Univ. Turfgrass Res. Summary. p. 56.

Bevard, D., J. Foy, T. Lowe, and B. White. 2005. Alternative grasses: Panacea or problem? U.S. Golf Assn. USGA Green Sect. Rec. 43:26-28.

Brede, D. 2000. Turfgrass maintenance reduction handbook: Sports, lawns, and golf. Sleeping Bear Press, Chelsea, MI.

Engelke, M.C., P.F. Colbaugh, J.A. Reinert, K.B. Marcum, R.H. White, B. Ruemmele, and S.J. Anderson. 2002a. Registration of 'Diamond' zoysiagrass. Crop Sci. 42:304-305.

Engelke, M.C., J.A. Reinert, P.F. Colbaugh, R.H. White, B.A. Ruemmele, K.B. Marcum, and S.J. Anderson. 2002b. Registration of 'Cavalier' zoysiagrass. Crop Sci. 42: 302-303.

Ferguson, M. and A.J. Newell. 2010. Evaluation of the bigmow automatic mower. Belrobotics S.A. Project No. TB101281. 20 June 2018. <https://www. belrobotics.com/sites/default/files/ Bigmow-report-STRI-en.pdf>.

Gibeault, V.A. and D. Hanson. 1977. Perennial ryegrass mowing quality and appearance response to three nitrogen regimes. Proc. 3rd Intl. Turfgrass Res. Conf., Munich, Germany. p. 39-43.

Grossi, N., M. Fontanelli, E. Garramone, A. Peruzzi, M. Raffaelli, M. Pirchio, L. Martelloni, C. Frasconi, L. Caturegli, M. Gaetani, S. Magni, J.S. McElroy, and M. Volterrani. 2016. Autonomous mower saves energy and improves quality of tall fescue lawn. HortTechnology 26:825830.

Hicks, R.W., II and E.L. Hall. 2000. Survey of robot lawn mowers. Proc. Soc. Photo-Optical Instrumentation Eng. 4197. Intelligent Robots and Computer Vision XIX: Algorithms, Techniques, and Active Vision. Boston, MA. p. 262-269.

Honda. 2018. Miimo at a glance. 20 June 2018. <https://www.honda.co.uk/ lawn-and-garden/products/miimo/ overview.html>.

Husqvarna. 2018. Husqvarna automower $105 / 310 / 315 / 320 / 330 X / 420 / 430 X /$ $450 \mathrm{X}$ operator's manual. 20 June 2018. <http://www.husqvarna.com/uk/ support/manuals-downloads/>.

Lee, J.P. and D.H. Kim. 2005. Improvement of green-up of zoysiagrass and cool season grass during early spring in Korea. Asian J. Turfgrass Sci. 19:103-113.

Lulli, F., M. Volterrani, N. Grossi, R. Armeni, S. Stefanini, and L. Guglielminetti. 2012. Physiological and morphological factors influencing wear resistance and recovery in $\mathrm{C} 3$ and $\mathrm{C} 4$ turfgrass species. Funct. Plant Biol. 39:214-221.

Magni, S., A. Pompeiano, M. Gaetani, L. Caturegli, N. Grossi, A. Minelli, and M. Volterrani. 2017. Zoysiagrass (Zoysia spp. Willd.) for european lawns: A review. Ital. J. Agron. 12:395-402.

Morris, K. 2016. Evaluation of warmseason grasses for putting greens. USGA Turfgrass Environ. Res. Summary. p. 241-243.

Morris, K.N. and R.C. Shearman. 2018. NTEP turfgrass evaluation guidelines. 20 June 2018. <http://www.ntep.org/pdf/ ratings $>$.

Munshaw, G. 2013. Mowing your kentucky lawn. Univ. of Kentucky, College of Agr., Food and Environ., AGR-209. 20 June 2018. <http://www2.ca.uky.edu/ agcomm/pubs/agr/agr209/agr209.pdf>.
Patton, A.J., M. Richardson, D. Karcher, and J. Trappe. 2010. 2007 Arkansas zoysiagrass trial: Year 3 results. Arkansas Turfgrass Rpt. 2009. Arkansas Agr. Expt. Stn. Res. Ser. 579:28-35.

Patton, A.J., B.M. Schwartz, and K.E. Kenworthy. 2017. Zoysiagrass (Zoysia spp.) history, utilization, and improvement in the united states: A review. Crop Sci. 57:S-37-S-72.

Pirchio, M., M. Fontanelli, C. Frasconi, L. Martelloni, M. Raffaelli, A. Peruzzi, M. Gaetani, S. Magni, L. Caturegli, M. Volterrani, and N. Grossi. 2018. Autonomous mower vs. rotary mower: Effects on turf quality and weed control in tall fescue lawn. Agronomy (Basel) 8(2):15.

Pompeiano, A., N. Grossi, L. Guglielminetti, and M. Volterrani. 2014. Winter color retention and spring green-up of zoysiagrass genotypes in southern Europe. Eur. J. Hort. Sci. 79:158-166.

Pompeiano, A., N. Grossi, and M. Volterrani. 2012. Vegetative establishment rate and stolon growth characteristics of 10 zoysiagrasses in southern Europe. HortTechnology 22:114-120.

Ragonese, A. and J. Marx. 2015. The applications of sensor technology in the design of the autonomous robotic lawn mower, Paper No. 5094. 15th Annu. Freshman Eng. Conf., 11 Apr. 2015, Pittsburgh, PA.

Robomow. 2018. Choose your best team player. 20 June 2018. <http://robomow. com/en-GB/product-category/mowers/>.

Shearman, R.C. and J.B. Beard. 1975. Turfgrass wear tolerance mechanisms: II. Effects of cell wall constituents on turfgrass wear tolerance. Agron. J. 67:211215.

Trappe, J.M., D.E. Karcher, M.D. Richardson, and A.J. Patton. 2011. Bermudagrass and zoysiagrass cultivar selection: Part 1, clipping yield, scalping tendency, and golf ball lie. Appl. Turfgrass Sci. 8:1-12.

Turgeon, A.J. 2012. Turfgrass management. Prentice Hall, Upper Saddle River, NJ.

Whereley, B.G., P. Skulkaew, A. Chandra, A.D. Genovesi, and M.C. Engelke. 2011. Low-input performance of zoysiagrass (Zoysia spp.) cultivars maintained under dense tree shade. HortScience 46:10331037.

Zucchetti. 2018. Ambrogio robot. 20 June 2018. <http://www.ambrogiorobot. com/en/ambrogiorobot $>$. 